sultants working in these hospitals are placed in a position of having to satisfy two apparently conflicting demands. On one hand they are still pressed by family doctors, parents, and local authorities to admit subnormal patients. On the other hand they are anxious to reduce the numbers in hospital to improve the working conditions of the staff and the quality of life of the patients. With a majority of inpatients in these hospitals on a permanent basis, and nowhere else to go, discharges are few and vacancies become occupied by more longstay cases.

The consultant may have doubts about the ability of an over-crowded and understaffed hospital to help the patients referred to him, and in some cases the consultant will suspect that hospital admission is sought mainly because nobody else wishes to accept the patient. A responsible consultant will also be mindful of not imposing on a depleted nursing staff too many difficult and even dangerous patients. If a patien spends 20 or 30 years in a hospital for the mentally subnormal, the cost to the taxpayer can range from $£ 15,000$ to $£ 20,000$. Admission for long-term care is a serious and a costly matter.

One answer to the dilemma would be to bring together the agencies involved to form an admissions panel to consider each case. It is suggested that this should include, in addition to the hospital consultant, a representative of the hospital's nursing service and administrative staff, the other members being the local authority medical officer, the mental welfare officer, and the family doctor, with the parents and relatives available for interview. The suggestion that nursing and administrative officers should have a say in the admission of a patient might seem unusual, but it is they who have to provide for a patient during 24 hours every day, perhaps for the rest of the patient's life. This procedure could also safeguard the consultant who finds himself expected to conspire in securing the admission to hospital of people who do not really require hospital care or whose needs cannot be fulfilled by the hospital.-I am, etc.,

Westwood Hospital,
Bradford 6, Yorks.

D. A. SPENCER.

REFERENC

1 Department of Health and Social Security, On the State of the Public Health, London,

\section{Evaluation of Simpson}

SIR,-Dr. W. B. Gough (30 May, p. 541) underestimates the character and achievements of Sir James Young Simpson. In his own time Simpson was criticized and indeed denigrated but this is the fate of the successful innovator. After a hundred years the feud is carried on and some misconceptions are perpetuated.

Simpson never claimed to have discovered general anaesthesia. In 1847 he was bold enough to exploit the newly discovered properties of ether for the relief of pain in childbirth. His greatest achievement in this field was to defeat the opposition of many of his colleagues and some of the clergy. His discovery of the use of chloroform as an alternative to ether advanced the art of anaesthesia and owed little or nothing to David Waldie.

Simpson is accused of excessive selfadvertisement. It was, however, the custom of the time to circulate the privately printed pamphlet (reprints of articles in journals were not usually readily available). How else could his laudable "one purpose of placing his views and enthusiasms before his colleagues" be achieved?

Simpson may be criticized for a failure to submit his ideas to adequate trials and for rushing into print. These things reflected the tempo at which he worked and lived. He saw with regard to many of his discoveries a necessity to establish them urgently for the benefit of mankind. If he was in a hurry to relieve women from unnecessary pain in childbirth they at least were grateful. Further, this urgency must be looked at against the contemporary medical scene with its jealousies and bitter feuds. Ethics over priorities were somewhat shaky and plagiarism was not unusual. Even today in scientific circles the urgent preliminary report is often published to establish priority. If at times Simpson did publish prematurely he almost invariably followed up the initial report with prolonged and careful statistical studies. Few of his colleagues took this trouble but issued ex cathedra statements unsupported then or later by any statistics.

Dr. Gough asks "apart from chloroform what have we?" We have from one man an astonishing list of inventions and ideas. A survey of his contributions to obstetrics and gynaecology would take up too much space. The air tractor, for example, was thought of by Dr. Neil Arnott but it was Simpson who sold the idea (and the technique has been revived today). In medicine and surgery one can always go back and find that someone has had the idea before but the credit must always go to the individual who persuades others that the idea is right.

I do not think that Mr. E. Gaskell's estimate of Simpson as a great pathfinder of medicine is wrong (16 May, p. 414). In so many fields he influenced all branches of medicine for good. I have read most of his published writings and much of his voluminous correspondence, and I am convinced that few in his century devoted themselves so wholeheartedly to the advancement of medicine and few showed such humanity Of course he had his weaknesses (as all great men have), but to talk of his activities as a "hollow sham" and to describe his writings as "pathetic" distorts the truth. He must be judged against the background of medicine in his own time and against his contemporaries. This I have tried to do in a recent biography. ${ }^{1}$ Judged even a hundred years later in the light of modern progress his achievements remain outstanding, and he can be summed up as a dynamic and brilliant leader.-I am, etc.

\section{Liverpool 1. JOHN SHEPHERD. \\ burgh, Edinburgh, Livingstone, 1969.}

SIR,-Dr. W. B. Gough (30 May, p. 541) is entitled to his prejudices and even to his peculiar views on how a man's greatness is to be measured, but he surely ought not to wave them so plainly in front of everyone's eyes. It is nonsense to paint Simpson one moment as a cheap publicist and the next as an "exceptional man"; and it is wrong to imply that Simpson's scientific greatness, or lack of it, depends on whether or not he thought of chloroform before Waldie. One of the differences between a great man and a mediocrity is the former's capacity to develop his ideas; not just to think them up.

If Dr. Gough is not satisfied with Simpson's work on chloroform then he should take a look at his (Simpson's) writings on cross-infection and on hospitals; not to mention his voluminous and, in the view of his recent biographer, $\mathrm{Mr}$. Shepherd, ${ }^{1}$ first-class work on many aspects of obstetrics and gynaecology (see also B.M.f., 17 January, p. 162). This was no puny pygmy, even less a perpetrator of "hollow shams"; as Dr. Gough would know if he did not insist on making judgements from the vantage point of science in 1970. In any case it seems to me antihistorical to build prestige ladders in the air and to spend one's time placing each of our forebears carefully, and as we think correctly, on their separate rungs.

Incidentally one of the objects of my rather modest article (16 May, p. 414) was to direct attention to Protheroe Smith, Simpson's correspondent in London. When writing it I was unaware of, and have since been told about, three further letters from Simpson to Smith published nearly 40 years ago. ${ }^{2}-\mathrm{I}$ am, etc. \section{E. GASKELL.
Wellcome Institute of the History of Medicine,}

REFERENCES

Shepherd, S. A., Simpson and Syme of Edinburgh, London, Livingstone, 1969.

burgh, London, Livin
Lancet, 1932, 2, 201.

\section{Xerophthalmia and Blindness}

SIR,-The article "Corneal Disease" in your Current Practice series (4 April, p. 33) made several references to practice outside the United Kingdom, but did not include vitamin A deficiency and xerophthalmia. This is still the most common cause of blindness in early childhood in many developing countries. As numerous reports attest $^{1-3}$ it is the combination of measles keratitis and the colliquative necrosis of vitamin A deficiency, not bacterial infection, that is so destructive of eyesight.

It may be true that 400 million people have or have had trachoma. This is not the same as saying that they "suffer" from it. A high proportion of patients in many countries are completely symptomless, and when there is impaired visual acuity this may often more correctly be attributed to accompanying secondary infection and trichiasis. It is high time that the popular myth of trachoma as "the world's most important eye disease" was exploded. It is not as common a cause of blindness as either cataract or glaucoma. What about the claim for xerophthalmia? After all it carries a $50 \%$ mortality and blinds an estimated 100,000 children annually4.

It has been a saddening part of my experience in my travels in many countries over the past 20 years to find ophthalmologists, local and expatriate, trained in Britain or the U.S.A., ignorant of xerophthalmia, one 